\title{
Review of the Evidence: The Interface between Poverty, Livelihoods, Institutions, and Community Development
}

\author{
Tadele Zemede Wubayehu ${ }^{1}$ \\ ${ }^{1}$ Department of Governance and Development Studies, College of Social Science, Wollega University, Nekemte, \\ Ethiopia \\ Correspondence: Tadele Zemede Wubayehu, Department of Governance and Development Studies, College of \\ Social Science, Wollega University, Nekemte, Ethiopia. Tel: 251-9-7800-2900. E-mail: arjozemede@gmail.com
}

Received: May 6, $2020 \quad$ Accepted: June 12, $2020 \quad$ Online Published: July 29, 2020

doi:10.5539/jsd.v13n4p104 URL: https://doi.org/10.5539/jsd.v13n4p104

\begin{abstract}
This paper seeks to critically review the existing literature on the links or interfaces between poverty, livelihoods, institutions, and community development. This discussion gives a clear understanding of how poverty is created and gives a clue of how sustainable policy intervention could be developed. The study adopted the Sustainable Livelihood Approach as an overall theoretical framework that guides this discussion. The reviewed literature shows that there are strong and complex interfaces between poverty, livelihoods, institutions and community development and they influence each other in several ways. The interfaces between these concepts influence the choices and nature of livelihood strategies that people employ to pursue their livelihood outcomes. The livelihood outcomes may be positive or negative and it is determined by how these concepts are linked together. For instance, the existing empirical evidences shows that having access to livelihood assets, investment in infrastructure, presence of enabling policy and institution result in positive livelihood outcomes whereas lack of access to assets, increased vulnerabilities, low investment in infrastructures, lack of popular participation, poverty and weak policy and institution together result in adopting of failed livelihood strategies which in turn resulted in negative livelihood outcomes. Thus, to formulate policies, strategies and programs that can effectively address poverty and result in sustainable development, policy makers should consider and understand the connection between these concepts before the formulation of policy, strategies or programs. Without understand this it is difficult to formulate policies, programs, and strategies that can positively contribute to poverty reduction and sustainable development.
\end{abstract}

Keywords: community development, livelihoods, livelihood strategies, institutions, poverty, sustainable development

\section{Introduction}

Purpose of this study is to discuss the interfaces between poverty, livelihood, institutions and community development. To meet this aim, the study merely used secondary data. Thus, both theoretical and empirical literatures that deemed necessary for this study were rigorously reviewed.

This study organized in to four major sections. The first section of the term paper sought to introduce the concepts of poverty, livelihood, institutions and community development. The second section, introduced the theoretical frameworks that underpinning this term paper that is Sustainable Livelihood Approach (SLA), the reasons why this approach adopted as an appropriate theoretical framework that guide this discussion will also presented in details in this section.

The third section, presents' reviews of both theoretical and empirical literatures evidences on the connection between poverty, livelihood, institutions and community development.

The last section provided the conclusion based on my views and reviewed empirical evidences. Moreover, sources consulted during the process of the work are properly acknowledged and hence, listed under bibliography. Generally, the paper concluded that there are strong and complex interfaces between these concepts and they influence each other in several ways. None of this concept is independent and free from the influences of others. 


\section{Concept and Definitions of Basic Terms}

This section embarks on the reviewing important theoretical literatures that deemed useful to conceptualize and define the basic concepts used in this term paper.

\subsection{Concept and Definitions of Poverty}

There is no consensus among scholars on definition and how to measure poverty in spite of its universality and the enormous literature on it. Thus, some scholars and institutions defined poverty in many ways and using many different standards. For instance;

According to Grusky and Kanbur (2006) the dominant Western definition since the second World War has defined poverty in monetary terms, using levels of income or consumption to measure poverty and defined the poor by a headcount of those who fall below a given income/consumption level (Lipton and Ravallion, 1993 cited in Handley et al., 2009). According to the United Nations Children's Fund (2000) poverty is most commonly defined as insufficient income to buy a minimum basket of goods and services. However, this economic definition of poverty has been now supported by other multidimensional approaches (basic needs approach, capabilities approach, human development approach, etc.) that define and measure poverty in a more multidimensional way. Some of these definitions are;

> Townsend (1979) argued that any person or society can be said to be in poverty when lack the resources to get the types of diet, participate in the activities and have the living conditions and amenities which are customary, or at least widely encouraged or approved, in the societies to which they belong. Their resources are so seriously below those ordered by the average individual or family that they are, in effect, let off from ordinary living patterns, customs, and activities.

$>$ Chambers (1995) defined poverty as deficiency of physical necessities, livelihood assets and income. It comprises but is more than being income poor.

$>$ United Nations (1998 cited in Gordon, 2005) poverty is a denial of choices and opportunities, a violation of human dignity. It means lack of participation in decision making and in civil, social and cultural life. It means shortage of basic needs, limited or lack of access to basic services, lack of access to land on which to grow one's food or a job to earn one's living, not having access to credit. It means insecurity, marginalization of people, households and communities, powerlessness, vulnerability to external and internal shocks, stresses; living in unsafe environment without access to basic services.

$>$ World Bank (2000) also argued that to be poor is to be hungry, to be sick and not cared for, to be illiterate and not schooled. However, for poor people, living in poverty is more than this. Poor people are particularly vulnerable to various shocks and risks which are outside their control. The poor often treated badly by the institutions of state and society and excluded from voice and power in those institutions.

$>$ Multidimensional poverty conceives of deprivation not only as a lack of material goods but also as a deficiency in other important areas such as social capital, human capital, power, and voice (Mowafi and Marwan, 2005).

$>$ Handley et al (2009) defined poverty as multi-dimensional, complementing an income-based conceptualization of poverty with a more holistic approach to the deprivations a human being may suffer. According to them, poverty includes low life expectancy and lack of a decent standard of living, lack of opportunities, and access to basic services as well as the perceptions of the poor themselves: their sense of hopelessness, powerlessness, dependence, and lack of self-confidence.

$>$ According to (Sen, 1999) defined poverty as lack of capabilities.

The above discussion shows that the concept of poverty is multi-dimensional. For long time, some authors narrow it to lack of adequate income or consumption, but recently others argue that a broader definition, which includes non-monetary indicators. Generally, there are much debate among scholars on how exactly poverty can defined. Despite variations among scholars on how to define poverty, some scholars' commonly defined poverty with lowness/lack of income, to buy basic needs (food, clothing, and shelter) (Admore, 2011; Olowa, 2015; and Danaan, 2017).

\subsection{Concept and Definitions of Livelihoods}

The literatures show the presences of much definitions of livelihoods; some having broad definitions and others more specific, encompassing concepts of assets and capabilities. For instance;

Most scholars in livelihoods and several international development agencies adopt the Chambers and Conway (1992) definition of livelihoods which embraces that: "a livelihood are comprises the capabilities, assets (stores, 
resources, claims and access), and activities that are necessary to make a living: a livelihood is sustainable which can it overcome with and recover from internal as well as external vulnerability, maintain or improve its capabilities and assets, and provide sustainable livelihood opportunities for the future generation; and which adds net benefits to other livelihoods at the local, national and global levels and in the short time and in the long term". Different types of livelihood assets have identified by some scholars and organizations. However, the five basic assets that are generally recognized within sustainable livelihoods theory are: natural, physical, human, financial and social capital assets (Ellis, 2000).

Currently, Keshav (2015) more broadly explained livelihoods are not only about income generation, but it's a holistic approach, which goes deeper than the noticeable income generation activities, into the background factors, which leads to adaptation of particular activities leading to livelihood outcomes.

Thus, all the definitions from different sources suggest that livelihood is a broad concept and encompasses things beyond mere income generation activity. As, Ayodeji, (2015) despite a presence of various definitions and approaches of livelihood, there is a common consensus that: "livelihood is concerned with the ways and means by which people make a living, and there is an agreement that for livelihood to contribute to poverty alleviation, it must be sustainable."

\subsection{Concept and Definitions of Institutions}

There is consensus among scholars on importance of institution for poverty reduction and as it matters much for development, but no consensus among scholars on its definition (Martin, 2006). Some scholars defined and conceptualized institutions several ways as;

Albu (2009) defined institutions as the rules, norms and processes that guide the interactions of the peoples with governments, markets and the environment. It comprises both formal and informal interactions that shape societal interactions. According to Leftwitch (2006) formal institutions are normally established and constituted by binding laws, regulations and legal orders which prescribe what is permissible or may not permissible be done. Informal institutions, in the other way, created in society based on their values, norms, beliefs and influence their interaction as well as their ways of doing things.

According to (North, 1990), institutions are the formal rules, connections and formal codes of behavior that guide human interactions. This definition is the most widely accepted definition of institution by some scholars (Boliari, 2007).

\subsection{The Concept and Definitions of Community Development}

Community development is an often-unclear term defined by many conceptual and practical descriptions (Summers, 1986; Wilkinson, 1991).

By merging the two different terms community and development, community development refers to the process in which local people take part in the process of decision-making and collective actions leading to an agenda of social change on equality, social inclusion, and poverty reduction (Motherway, 2006 as cited in Ali,2016).

Community development processes focused on economic development concerns establishment of local efforts aimed at improving the community's resources. It linked directly to poverty reduction; development, and development of local businesses; reduction of economic leakages; employment creation, and income generation (Marais \& Botes, 2007; Taylor, 2007).

Recently (David Matarrita-Cascante \& Mark A. Brennan, 2012) defined community development as a process that involves organization, facilitation, and action, which allow the people to create the type of community they want to live in. It is a process that offers vision, planning, direction, and coordinated action towards desired goals associated with promotion of efforts aimed at improving the conditions in which local resources use. Thus, local resources used to secure their daily needs and respond to changing environments or conditions.

\section{Theoretical Framework: Sustainable Livelihoods Approach}

This section discusses the theoretical framework underpinning this study. This study adopted Sustainable Livelihoods Approach (SLA) as the overall theoretical approach that guide the discussion on the connection or interfaces between poverty, livelihoods, institutions, and community development and to understand how they influence each other.

The Sustainable Livelihood Approach (SLA) is essentially an approach to holistically understand the livelihoods of the people living in poverty with a view to developing effective poverty intervention strategies. On the one hand, it focuses on the capacities of poor and, on the other hand, other external factors both at micro and macro level the influence people's livelihoods and how these factors interact (livelihood assets, vulnerability context, institutional 
context, livelihood strategies) to decide people's livelihoods outcomes.

A livelihoods approach to poverty and livelihood analysis, therefore, provides a comprehensive platform for understanding the links between livelihood access, assets, context and institution and their effects on individual, household or community asset accumulation (Bebbington, 1999). The sustainable livelihood framework is generally divided into five parts: Livelihood assets, vulnerability context, Policies, Institutions and Processes, livelihood strategies and livelihood outcomes. But, in this framework the concept of community development is not considered. So, for the purpose of this study, SLA was modified to show how the issues of community development can considered or included in this framework by reviewing both theoretical and empirical literatures related to issues under investigation. Thus, all these concepts were brought together under SLA and shown here under in figure 1.

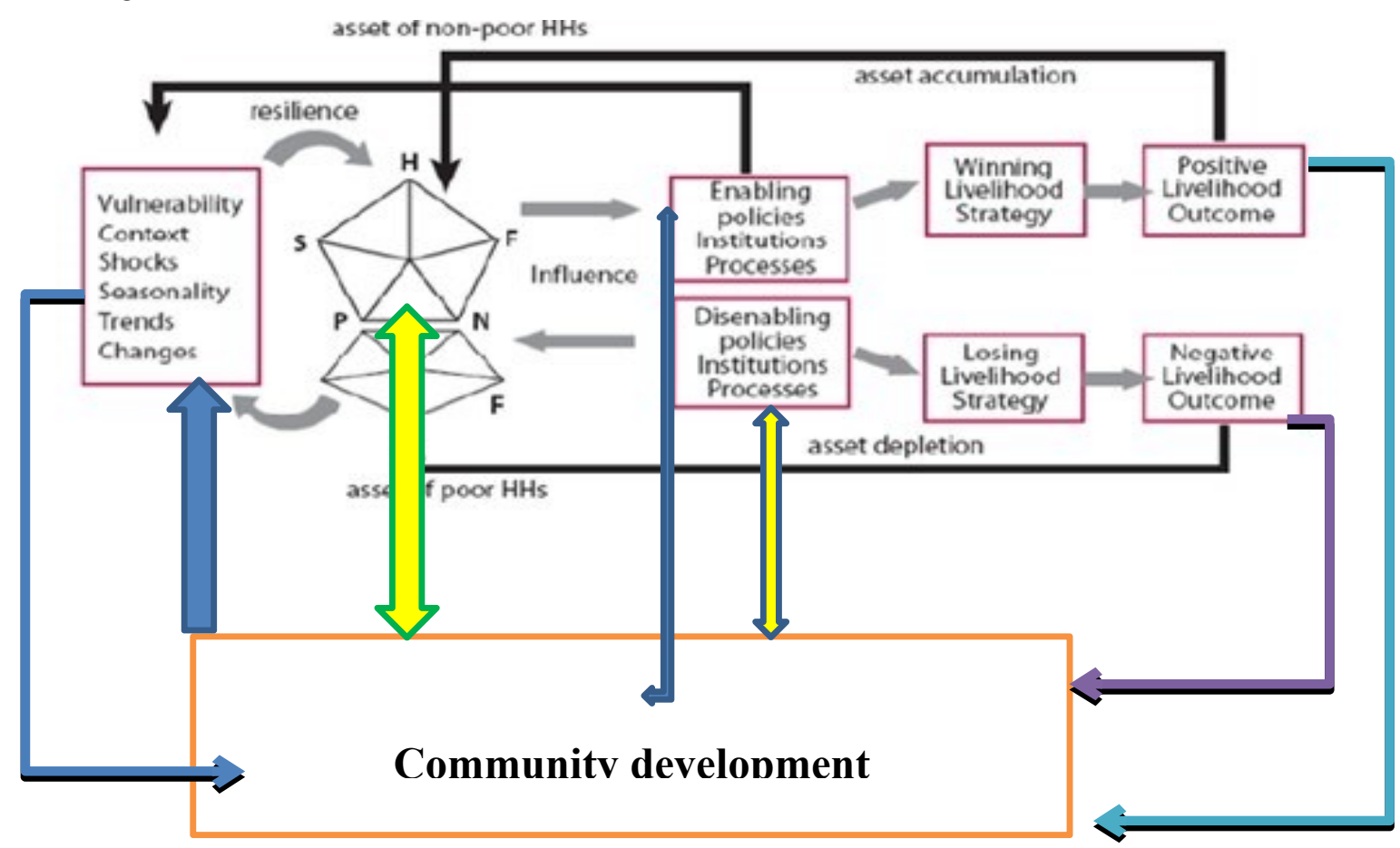

Figure1. Modified SLA framework: Livelihoods and poverty

Source: Adopted and modified by the Author from Carloni and Crowley (2005).

\section{The Interface between Poverty, Livelihoods, Institutions, and Community Development}

This section presents the review of empirical evidences on the connection or interface between poverty, livelihoods, institutions, and community development. The reviewed literature shows that there are strong and multifaceted interface between poverty, livelihoods, institutions, and community development and they also influence each other in several ways. The interfaces between these concepts, therefore, presented as follows;

Proponents of sustainable livelihood have advocated that it is conceptually and methodologically proper to start the analysis/discussion with assets owned, controlled, accessed by individual, household or community (Ellis, 2000). This study, therefore, also started discussion from livelihood assets. Livelihood literatures show that access to livelihood assets is the key determinant of poverty.

The starting point is the recognition that asset is at the core of livelihoods and poverty (Department for International Development, 1999) and livelihood assets recognized as the foundation upon which livelihoods constructed on (Elasha, 2005). Some scholars and institutions have identified different assets, however, the five basic assets that generally recognized within sustainable livelihoods theory are: natural capital, physical capital, human capital, social capital and financial Capital (McLeod, 2001).

Significance of assets on livelihood construction, reducing vulnerabilities of the poor, reducing poverty, and improving sustainable livelihood outcomes studied to the great extents. In this respect, it is recognized that assets are essential elements in the livelihood framework which enables the people to survive, engage in different activities and participate in reciprocal exchanges with other households (Moser, 1998). Besides, (DFID, 1999) 
forwarded that, livelihood assets are resources needed by household or individual and community not only to provide for just basic needs, but also to build a sustainable livelihood. The significance of assets to sustainable livelihoods and poverty alleviation is generally recognized by some scholars and organizations (Elasha, 2005). This directly or indirectly shows the presence of interfaces between livelihood, poverty, institution and community development. Livelihood assets alone are not sufficient enough to achieve sustainable livelihoods and poverty alleviation; because accesses to assets are influenced by vulnerability context, poverty, institutional context, and community development. So, it is the ways these concepts integrated which determine the livelihood strategies adopted by the people, sustainable livelihoods construction, and poverty alleviation.

Specifically, some scholars revealed there are strong connections or links between livelihoods and poverty. For instance, Admore (2011) and Ayodeji (2015) argued that access to assets is an important determinant of poverty. Christensen and Pamela (2008) explained that the five livelihood assets. The access to livelihood assets is the key factor to staff off people from poverty or to meet better livelihoods. Similarly, it is also argued that livelihood resources enable people or household to build ability to withstand vulnerability to shocks and stresses (Mpamba, 2015). As per (Rakodi, 1999) noted, access to assets defines people's competence to achieve improved well being. Thus, having access to sufficient and balanced assets is, essential for empowerment and for living above poverty.

On the other hand, lack of access and control over assets is one among a major cause and consequences of poverty, and reason that spreads poverty. According to Agbaje et al. (2013) poor people living in poverty generally have limited access to various forms of asset needed to build a sustainable livelihood. Therefore, owning or having access to the five assets important for an individual, households or community livelihood to stave off poverty and enhance sustainable livelihood outcomes. On contrary to this lack of access to these important assets is one of the major causes for poverty. This is more elaborated by Sen (1981) successful livelihood assets transform assets into income, dignity, and agency, to improve life style, a prerequisite for poverty reduction.

The above discussion shows that accessible livelihood assets can influence the livelihood alternatives of the individual, household or community. But, the five assets are not the sole reason that makes the people to get sustainable livelihood. Thus, this part of discussion analyzed how other conditioning factors to influence the access livelihood assets such as vulnerability context, poverty, institutional context and community development.

How access to livelihoods assets affect poverty was elaborated above. This section presents what influence livelihood and accesses to it. In this favor, it is argued that assets interact with the prevailing institutions to create livelihood opportunities or vulnerabilities (World Bank, 2001). Similarly, Admore (2011) clearly showed that access to important assets hinge on institutional arrangements comprising power and politics. The already established institutional arrangements in that particular area may have direct or indirect impacts on the livelihood outcomes of those particular residents.

As it has shown in the SLA, vulnerability context can directly influence livelihood assets and directly influenced by livelihood assets and institutional contexts. In this respect, Carloni and Crowley (2005) argued that a vulnerability context (internal and external) affects individuals' asset portfolios and livelihoods outcomes. According to Carloni and Crowley (2005) vulnerability causes people to lose their assets. The losses of valuable assets lead poor people to become poorer. That means household with less assets are much more vulnerable to poverty than household with more assets. On the other hand, larger number of assets helps the poor more resilient to withstand the shocks (Food and Agriculture Organization of the United Nations, 2015). This shows that there are two-way relationships between assets and vulnerability. In one way, assets help protect people's livelihoods against vulnerability and on the other side, lack of access to assets increases vulnerability of the poor. As such, lack of assets is manifestations of vulnerability and poverty.

Scoones et al (1996) make a link between external vulnerabilities, livelihoods and vulnerability that increased risks. Both internal and external vulnerabilities can undermine rural or urban livelihoods in a way that increases vulnerability, resulting in impoverishment and powerlessness. These ideas of Chambers and Scoones support the view that poverty is a result of one 's being vulnerable to risks, shocks and stresses. Poverty then also affects livelihoods as rural / urban dwellers fail to meet sustainable livelihood outcomes.

From the above discussion, the interface between livelihood, vulnerability and poverty can expressed as follows; on one way, lack of access to livelihood increases vulnerability of the people and force them to live in poverty. On the other way, vulnerabilities and poverty can adversely undermine the livelihood of the poor. According to Mpamba (2015) vulnerability of the poor increased when there are no strong institution, strong policies and strategies that promote and protect the rights of poor, and no popular participation in policy formulation. He clearly stipulated that archaic policies have denied the right of mobility to pastoralists while looking for forage and water 
(natural asset), the policy makers did not allow them to take part in policy formulation and decide what is best for them this led to policy failures and increases of vulnerability to pastoralists. Therefore, as noted by Messer and Townsley (2003) peoples may called poor when they have no enough livelihood assets as a result of no access to assets, severe vulnerability, and weak institution that deter people's ability to pursue enough livelihood.

The above discussion shows presences of strong links between livelihood, poverty and institution. So, this part of discussion shows the way how institution affects livelihoods, poverty and community development and it is influenced by these concepts. Cannon et al. (Nd) noted that it is the institutional contexts that influence both livelihood opportunities and vulnerability of people.

According to Crowley (2005), institutions have both direct and indirect impacts on people's livelihoods. According to Carloni and Crowley (2005), institutions influence household livelihood directly, by determining which activities are permissible/ impermissible and legal/ illegal. Similarly, institutions influence household livelihood indirectly through their influence on access and control of resources. Institutional context can support or inhibit livelihoods of the poor, as (Carloni and Crowley, 2005) stated; enabling policy and institutional environment facilitates the condition how poor or less poor people get access to livelihood assets that required for making living or further livelihood improvement. On the other hand, a disabling policy and institution deter them from getting access to these resources. It also recognized that, the interactions between policy, institutions and process (PIPs) and vulnerability context influence the extent of people's access to or control over assets, which ultimately decide their livelihood outcomes (Farrington et al., 2002; Albu, 2009, and Ayodeji, 2015).

Baker and Schuler (2004) also noted that institutions, particularly government institutions, are responsible for creating conducive environment for people to increase their capacities to respond to external vulnerabilities, to build sustainable livelihoods, and to improve human well - being. Cannon et al. (undated) also highlight the role of institutions in reducing vulnerability, by creating opportunities for people and providing enabling environments for people to claim their human rights. Nevertheless, the existing public institution and policies in some of developing countries are not creating these opportunities for the people instead it deprives their basic human rights. Consequently, a large proportion of the population lives in poverty. Poverty is an outcome of multiple deprivations of human rights or denial of rights results in livelihood insecurity.

This more clearly explained by Albu (2009), institutional context (strong and weaknesses) are key factors in poverty. Therefore, institutions have potentials for enhancing or reducing various dimensions of poverty, as they shape people access to livelihood assets, and investment infrastructures (Admore, 2011). The one among the primary functions of government is the provision and maintenance of different infrastructures through its various agencies. Some empirical evidence shows that, community development projects or investment in infrastructure is fundamental to livelihood sustainability (Mazibuko, 2017). However, governments particularly in developing countries are fails to discharge these responsibilities. This is one of among the major reasons why the fails to escape their country from poverty trap.

Any government that is serious about alleviating poverty must, therefore, make infrastructure available for the poor. As Baker and Schuler (2004) investment in infrastructures can enhance and improves the tools that people use to generate their livelihoods and well - being. Policies and processes of infrastructure and service provisions therefore, influence the nature, quality and quantity of services accessible to people and the way they use it for making a living (Messer and Townsley, 2003).

The above discussion shows that weak state institutions have adverse impacts on individual or community livelihoods, vulnerability of the poor, poverty reduction, community development and sustainable development. To address this, it recommended that, to meet sustainable poverty alleviation, institutions must be accountable to the poor (Ayodeji, 2015). Unfortunately, institution found in many developing countries is not accountable to the people.

Regarding to how community development, linked to poverty, livelihood and institutions. The empirical evidences on community development show that community development can affect livelihood, poverty reduction, and institutional capacity. It is the community development approach which introduced to the world the idea of facilitating the development process to raise peoples' living standard. To achieve this, five basic resources available with people at community level needs should give attention to. These five are: physical, financial, human, social and natural (Scoones, 2009). Scoones briefly explain livelihood as a means for gaining living. He argued that the proper use of these resources, policies, institutions and organizations are necessary to flourish their capabilities and support them in initiating appropriate development interventions.

According to Ali (2016) through community development local people are empowered to work on their own issues with reference to their prioritized agendas to improve quality and standard of their life. Despite the challenges such 
as community values, differences in confidence, perception, beliefs and levels of participation, government level bureaucracy and lack of coordination with stakeholders, community development has faced in contributing to the rural livelihood it has gained numerous success too (Ali, 2016; Imanishimwe, et.al. 2018). Similarly, community development processes focused on economic development concerns the establishment of local efforts aim improving the community's resources. It linked directly to poverty reduction; development, and development of local businesses; reduction of economic leakages; employment creation, and income generation (Marais \& Botes, 2007; Taylor, 2007).

Other empirical evidences also show that, women participation in different community projects contributed to empowerment of women and their livelihood improvements (Mazibuko, 2017). Similarly, study conducted by Nziane (2009) shows that community development projects have many contributions to the community. The impact of community development according to him includes that job creation and income generation. Thus, increased in income and job opportunities result in diversification of livelihood assets, enhance capabilities to cope up with vulnerability, poverty and ensure sustainable livelihood outcomes.

In the above discussion, contributions of community development on improvements of livelihoods and poverty reduction were identified. Besides, Yaekob (2018) found that community participation in decision-making and community development projects are important because it contributes to beneficiary's employment and grassroots institutional empowerment and an essential ingredient for sustainability of any development initiative. This is more broadly explained by Christenson (1989) development increases the possibility of choices; positive attitudes sustain, enhance functions of institutions and ultimately improve quality of life. The above discussion shows that there are strong and complex interfaces between livelihoods, poverty, institution and community development and they influence each other in several ways.

The interface between livelihoods, poverty, institution and community development determine the livelihood strategies of people and the adopted livelihood strategies in the particular situations/contexts then influence livelihood outcomes of the individual or households. This briefly discussed as follows;

As indicated in sustainable livelihoods frameworks, livelihood strategies are a comprehensive term used to denote different activities and choices that people make to achieve their livelihood goals (DFID, 1999). It is important to note that people's capability to overcome poverty is linked to the amount of choices and flexibility they have in their livelihood opportunities. However, as earlier mentioned, livelihood opportunities of the poor are determined to a large extent by the range of assets available to them to pursue different activities, vulnerability contexts, institutional contexts, and community development. Finally, these linked together and then influence people's choices of livelihood strategies. Then, the adopted livelihood strategies with in that particular context/s influence livelihoods outcomes. Livelihood outcomes classified in to two that are positive or negative. This result, vary based how livelihood, vulnerability context, poverty, community development and adopted livelihood strategies linked together. In this regard, literatures show that positive livelihoods outcomes helping households to become more resilient and less vulnerable, ensure their food security, sustainable development whereas negative livelihoods outcomes result in a further erosion and decrease of the asset base which in turn increase the vulnerabilities of people, and level as well as dimensions of poverty (Chambers and Conway, 1992).

The reviewed empirical evidences show that, positive livelihood outcome obtained when peoples have access to livelihood assets; able to diversify their own livelihood activities, government investment in infrastructures, enabling policy and institution are there in that particular area urban or rural, at local or national level. In turn, positive livelihoods enhance their capacity to diversify their livelihood assets, to cope up with external vulnerability, increase in investment infrastructures and finally, realize sustainable development.

On the contrary to this, negative livelihood outcomes are the results of lack of assess, inability of the poor to cope up with internal and external vulnerabilities, absence /poor infrastructures, lack or limited access to basic social services, disabling policy and institution. Failed livelihood strategies (e.g. migration, selling of valuable assets, reducing consumption patterns, relaying much on natural resources, lack of diversified livelihood, informal settlements, rely on natural resource, etc.) which result in negative livelihood outcomes, (increased vulnerability, degradation of livelihood assets, food insecurity, serious poverty).

Many empirical evidences have shown links between livelihood strategies, poverty, and resource use patterns (Opoku, Mohammed, 2011). For instance, some scholars, found that livelihood strategies employed on the basis of natural resources like selling of charcoal and woods, clearing of forests for farming are not sustainable and have potential to escape them out of poverty (Babulo et al. 2008; Liyama et al. 2008; cited in Mohammed, 2011, Diriba, 2012). In these studies, negative livelihood outcomes worsen the future of the poor leading to a downward spiral (Niehof 2004; Shanta et.al. 2009). Furthermore, Zemede (2015) conducted a study, to investigate socio-economic 
challenges and survival strategies of non- pensioned elders. The findings of the study shows that majority of the elders in the study area were asset less as a result of this they are forced to live in poverty. This is due to the fact that they has no access to different livelihood assets, government policies, programs and strategies designed to address poverty widely excluded them due to their age, the recent inflationary environment witnessed from the year 2007 (price hicks) also eroded the savings, incomes, and investments they made throughout their life. As a result of this, they were facing multiple socio-economic problems like, housing, health, access to basic healthcare, food shortage, financial insecurity, limited options of livelihood diversification and poverty. Consequently, they engaged in all kinds of odds jobs such as daily labor works, small business and mixed farming as their economic survival strategies. However, they failed to cover their cost of basic needs, they adopted substandard coping strategies like reducing consumption patterns, forcing family member to work, sale of assets, asking support from their extended family, and asking for alms (begging) as an alternative coping strategies to minimize the gap between their income and basic needs. The findings also shows that, the livelihood strategies employed by the elders is not sustainable which can bring them out from poverty trap instead it allow them to persist in Poverty and increases their vulnerabilities.

\section{Conclusion}

This study has brought together, four complex concepts poverty, livelihood, institution and community development. Regarding to the definitions of these concepts, different scholars and institutions have defined and conceptualized them in various ways. There is no universally accepted definition of poverty, livelihood, institution and community development. Thus, scholars in this fields and different institutions working in these areas have been conceptualizes and defined these terms in contexts of their studies and discussion.

The reviewed empirical evidences show that there are strong and complex links between poverty, livelihoods, institutions, and community development and they influence each other in several ways.

It is widely recognized by some scholars and institutions as; livelihood assets are bases up on which livelihood outcomes built on. Access to livelihood can determine the livelihood outcomes of the people. Specifically, having access to livelihood assets increases the capacities of the individual, households and community to become more resilient to both internal and external vulnerabilities, live above poverty trap, and obtain sustainable livelihood outcomes. On contrary, lack of access to livelihood assets increases the vulnerabilities of the poor and forces them to live in poverty trap.

From the discussion, poverty are the results of lack of access to livelihood assets, inability of the people to respond both internal and external vulnerabilities, lack of popular participation in decision-making, social discrimination and exclusion, lack/ limited access to basic services, disabling policy and institution. Thus, enabling policy and institution enhance and improve the livelihood assets and activities of the people by allowing them to have access to important livelihood assets; by protecting and safeguarding their rights in accessing and owning these assets, allow the people to take part in decision-making, by improving investment in different infrastructure, by improving access and qualities of basic social services, by expanding and supporting investment in infrastructures and etc. These together results in increasing capacities of the individual or household or community to become more resilient to both external and internal vulnerabilities, live above poverty trap, and meet sustainable livelihood outcomes. Strong policy and institution are also the result of having access to livelihood assets, participation in decision-making, responsiveness of public servants, accountability of public institutions to the people they serve, investment in infrastructures and provision of basic services like schools, health, water, road, telecommunication which enhances the capacities of the people to influence their on livelihoods, institutions and etc.

As a result, these concepts are very interrelated concepts which cannot be viewed and considered independently. Thus, to achieve sustainable poverty reduction and realize sustainable development, policy makers, development practitioners, and governments should have to understand and identify these links before formulation of policies. If policy makers and government fail to understand how poverty is created, they never formulate proper policy, programs and strategies that can address the problems that poor people are facing in their livelihoods particularly in developing countries including Ethiopia. These findings have a profound implication on the development policies of developing countries particularly in countries were all poverty reduction efforts taken at international, regional and national levels over the past three decades failed to achieve the desired goals. Finally, this study revealed that, there is a death of studies that have explored the connection or interfaces between these concepts and identified the way they influence each other in specific ways. This knowledge gap demands a mega research.

\section{Acknowledgements}

First and foremost, I would like to thank the almighty God who made this article to be a successful. 
Many people have supported me in countless ways in making this work a reality. Hence, I would like to take this opportunity to express my sincere gratitude to them all. First and foremost, I would like to express my profound gratitude to my Supervisor DR. Asebe Regasaa (Associate professor of Development studies), for his tremendous insight and scholarly support in the course of this study. His constructive feedback and suggestions added a great value to this work. I am highly indebted to my reviewers at (Journal of Sustainable development), for their unconditional support, suggestions and critical feedbacks from the inception to the end of this work. Their unreserved support had a significant impact on the present form of this Article.

\section{References}

Admore, T. M. (2011). Livelihood Strategies of the Aged People in Mubaira Community (Unpublished PhD dissertation). University of Fort Hare, Zimbabwe.

Agbaje, M. A., Okunmadewa, F. Y., Omomona, B. T., \& Oni, O. A. (2013). An Assessment of Vulnerability to Poverty in Rural Nigeria. ARPN Journal of Agricultural and Biological Science, 8(1), 60 - 75.

Albu, M. (2009). Pro - poor market approaches Steps towards a constructive dialogue. In Sustainable Livelihoods Highlights: Research Findings for Development Policymakers and Practitioners. Brighton: Institute of Development Studies (IDS).

Ali, M. N. (2016). Exploring the contribution of Community Development to the rural livelihood. Unpublished $\mathrm{PhD}$ dissertation). University of Bradford, School of Social and International Studies. Retrieved from https:// www.research gate.net/publication/304352281

Ayodeji, O. O. (2015). Understanding the complexity of factors which influence livelihoods of the urban Poor in Lagos' Informal Settlements. (Unpublished PhD dissertation). Newcastle University, England.

Baker, J., \& Schuler, N. (2004). Analyzing Urban Poverty, A Summary of Methods and Approaches (World Bank Policy Research Working Paper 3399). Washington D.C. https://doi.org/10.1596/1813-9450-3399

Bebbington, A. (1999). Capitals and Capabilities: A Framework for Analyzing Peasant Viability, Rural livelihood and poverty. World Development, 27(12), 2021-2044. https://doi.org/10.1016/S0305-750X(99)00104-7

Boliari, N. (2007). Conceptualizing Institutions and Organizations: A Critical Approach. Journal of Business \& Economic Research, 5(1). https://doi.org/10.1016/S0305-750X(99)00104-7

Carloni, A. S., \& Crowley, E. (2005). Rapid Guide for Missions: Analyzing Local Institutions and Livelihoods. Rome: Food and Agriculture Organization of the United Nations (FAO).

Chambers, R. (1995). Poverty and Livelihoods: Whose Reality Counts? ID Discussions paper 347. https://doi.org/10.1177/095624789500700106

Chambers, R., \& Conway, R. (1992). Sustainable Rural Livelihoods: Practical Concepts for the 21st Century. IDS, 296.

Danaan, V. V. (2017). Analyzing Poverty in Nigeria through theoretical Lenses. Journal of Sustainable Development, 11(1). https://doi.org/10.5539/jsd.v11n1p20

David, M.-C., \& Mark, A. B. (2012). Conceptualizing community development in the twenty-first century. Community Development, 43(3). https://doi.org/10.1080/15575330.2011.593267

Department for International Development (DFID). (1999). Sustainable Livelihoods Guide Sheets. London: DFID. Retrieved from http://www.livelihoods.org/info/ guidance-sheets-pdfs/section4_1.pdf

Elasha, B. E. (2005). Sustainable Livelihood Approach for Assessing Community Resilience to Climate Change: Case Studies from Sudan.

Ellis, F. (2000). Rural Livelihoods and Diversity in Developing Countries. New York: Oxford University Press.

Gordon, D. (2005). Indicators of Poverty \& Hunger. Expert Group Meeting on Youth Development Indicators United Nations Headquarters, 12th - 14th December 2005. New York.

Grusky, D., \& Kanbur, R. Y. (2006). Introduction: The conceptual foundations of poverty and inequality. In D. Grusky, \& R. Kanbur (Eds.), Poverty and Inequality. Stanford: Stanford University Press.

Handley, G., Higgins, K. C., Sharma, B., Bird, K., \& Cammack, D. (2009). Poverty and poverty reduction in subSaharan Africa: An overview of the issues.

Imanishimwe, A., Niyonzima, Th., \& Nsabimana, D. (2018). Contribution of Community Conservation and Ecotourism Projects on Improving Livelihoods and Sustainable Biodiversity Conservation in and around 
Nyungwe National Park (NNP). Journal of Tourism \& Hospitality. https://doi.org/10.4172/21670269.1000363

Keshav, A. (2015). Livelihoods of the Urban Poor: Case of Varanasi City in Uttar Pradesh in India. Disaster Risk Management in Dhanbad district of Jhar Khand in India. https://doi.org/10.2139/ssrn.2699426

Leftwich, A. (2007). What are Institutions? drian IPPG Briefing Paper No. One. IPPG Programme Office, IDPM, School of Environment \& Development, University of Manchester, Harold Hankin Building, Precinct Centre, Oxford Road, Manchester M13 9PL.

Marais, L., \& Botes, L. (2007). Income generation, local economic development and community development: paying the price for lacking business skills? Community Development, 42(3), 379-395. https://doi.org/10.1093/cdj/bs1021

Martin, G. H. (2006). What Are Institutions? Journal of Economic Issues. https://doi.org/10.1080/00213624.2006.11506879

Mazibuko, E. F. (2017). The Participation of Women from Rural Areas in Development Projects for Sustainable Livelihoods: A Case of Community Groups in Maqongqo Area, KwaZulu-Natal Province. (Un published MA thesis).

Mazibuko, E. F. (2017). The Participation of Women from Rural Areas in Development Projects for Sustainable Livelihoods: A Case of Community Groups in Maqongqo Area, KwaZulu-Natal Province. (Unpublished MPA thesis). At Stellenbosch University. Retrieved from http://hdl.handle.net/10019.1/100823

Mcleod, R. (2001). The impact of Regulations and Procedures on the Livelihoods and Asset Base of the Urban Poor: A Financial Perspective. Paper Presented at the International Workshop on Regulatory Guidelines for Urban Upgrading. Bourton - on - Dunsmore, May 17 - 18, 2001.

Messer, N., \& Townsley, P. (2003) Local Institutions and Livelihoods: Guidelines for Analysis. Rome: Food and Agriculture Organization of the United Nations (FAO).

Mohammed, A. O. (2011). Understanding livelihood strategy-poverty links: empirical evidence from central highlands of Ethiopia. Environ Dev Sustain, 13.

Mowafi, M., \& Khawaja, M. (2005). Poverty. Journal of Epidemiology \& Community Health 59, 260-264. https://doi.org/10.1136/jech.2004.022822

Mpamba, M. B. (2015). Livelihood Challenges (vulnerability) among the Datoga Pastoralists in Basutu and Basodesh Ward. (Unpublished Master). University of Tanzania.

North, D. (1990). Institutions, Institutional Change, and Economic Performance. New York: Cambridge University Press. https://doi.org/10.1017/CBO9780511808678

Olowa, O. W. (2015). Concept, Measurement and Causes of Poverty: Nigeria in Perspective. American Journal of Economics, 2(1).

Opoku, B. E. (2012). Coping with Urban Poverty; An Examination of Household and Individual Livelihood Strategies in Ghana. (Unpublished MA thesis).

Rakodi, C. (1999). A Capital Assets Framework for Analyzing Household Livelihood Strategies: Implications for Policy. Development Policy Review, 17, 315-342. https://doi.org/10.1111/1467-7679.00090

Scoones, et al. (1996). Hazards and Opportunities: Farming Livelihoods in Dryland Africa: Lessons from Zimbabwe. London: Zed Books Ltd.

Scoones, R. (2009). Livelihoods Perspective and Rural Development. Journal of Peasant Studies, 36. https://doi.org/10.1080/03066150902820503

Sen, A. (1999). Development as Freedom. New York: Randon House, Inc.

Shanta, P. K., Deng, W., Paudel, B., \& Raj, J. K. (2009). Household Livelihood Strategies and Implication for Poverty Reduction in Rural Areas of Central Nepal. Academic Editor: Harald Rohracher.

Summers, G. (1986). Rural development. Annual Review of Sociology, 12, 347-371. https://doi.org/10.1146/annurev.so.12.080186.002023

Taylor, G. (2007). What is community development? Brazos: Agricultural Communications, The Texas A\&M university system.

United Nations Children's Fund. (2000). Poverty Reduction Began with Children. New York: UNICEF. 
Wilkinson, K. (1991). The community in rural America. Middleton: WI: Social Ecology Press.

World Bank (2000). Taking Action to Reduce Poverty in Sub - Saharan Africa: An Overview. Washington D.C: The World Bank.

World Bank. (2001). The World Development Report. New York: World Bank.

Yaekob, T. (2018). Assessment of Community Development Practices: The Role of "Kale Heywot" Church Development Program in Selected Project Areas of "Gamo Goffa" Zones, Southern Nations, Nationalities and People Region. (Unpublished MA thesis). At Addis Ababa University, Ethiopia.

Zemede, T. W. (2015). Socio-Economic Challenges and Survival Strategies of Non- Pensioned Elders: The Case of Shambu Town, Horro Guduru Wollega Zone, Oromiya Regional State. (Unpublished MA thesis). Hawassa University, Ethiopia.

\section{Copyrights}

Copyright for this article is retained by the author(s), with first publication rights granted to the journal.

This is an open-access article distributed under the terms and conditions of the Creative Commons Attribution license (http://creativecommons.org/licenses/by/4.0/). 